\title{
Spiroplasma citri gen. and sp. n.: a Mycoplasma- Like Organism Associated with "Stubborn" Disease of Citrus
}

\author{
P. SAGLIO, M. LhOSPITAL, D. LAFLÈCHE, G. DUPONT, J. M. BOVÉ,
} J. G. TULLY, AND E. A. FREUNDT

\begin{abstract}
Station de Physiologie et de Biochimie Végétales, Centre de Recherches de Bordeaux, Institut National de la Recherche Agronomique, 33, Pont-de-la-Maye, France, Laboratory of Microbiology, National Institute of Allergy and Infectious Diseases, Bethesda, Maryland 20014, and Institute of Medical Microbiology, University of Aarhus, Aarhus, Denmark
\end{abstract}

The mycoplasma-like organisms observed in the sieve tubes of citrus plants affected by "Stubborn" disease have been obtained in pure culture in various media. The cultural, biological, biochemical, serological, and biophysical properties of a California and a Morocco isolate have been determined. Classical fried-egg colonies were observed. An anaerobic environment $\left(5 \% \mathrm{CO}_{2}\right.$ in nitrogen) favored growth on solid medium. Horse serum or cholesterol was required for growth. The temperature for optimal growth was $32 \mathrm{C}$. The organisms passed through $220-\mathrm{nm}$ filters. Positive reactions for glucose and mannose fermentation and phosphatase activity were obtained. Negative reactions were observed for esculin fermentation, arginine and urea hydrolysis, and serum digestion. All biochemical and biological reactions were identical for both isolates except for tetrazolium reduction and hemadsorption tests. The organisms were resistant to penicillin but sensitive to tetracycline, amphotericin $B$, and other inhibitors. The cell protein patterns of the two strains were identical to each other but clearly distinct from those for known mycoplasmas. The guanine plus cytosine content of the deoxyribonucleic acid of both strains was close to $26 \mathrm{~mol} \%$, and their genome size measured $10^{y}$ daltons. The studies reported here show that the two organisms recovered from "Stubborn"-affected citrus plants comprise a single serological group and that they are serologically distinct from recognized Mycoplasma and Acholeplasma species in the order Mycoplasmatales. The cultural, biochemical, and biophysical properties of the organisms support the serological results, confirm the unique nature of these organisms, and justify their placement in a new genus, Spiroplasma, as a new species, S. citri. S. citri is the type species of the genus Spiroplasma. The Morocco strain (=R8-A2), designated as the type strain of $S$. citri, has been deposited in the American Type Culture Collection as ATCC 27556; the California strain $(=\mathrm{C}-189)$ has been deposited as ATCC 27665 . The taxonomic position of $S$. citri is discussed. The final decision on the assignment of the citrus agent to either the class Mollicutes or the class Schizomycetes must await further analysis.

After the discovery of mycoplasma-like structures (MLS) in the phloem tissues of plants infected with mulberry dwarf, potato witches' broom, aster yellows, or Paulownia witches' broom (13), similar structures were soon found to be associated with many other affections of plants, all of which were considered until 1967 to be of a viral nature. Several recent reviews discussed MLS in various plant diseases $(10,24$, $27,37,55$ ).
In the case of citrus, the first structures to have been described in the sieve tubes of affected plants were those associated with "greening" disease (31). However, it was soon realized that these structures were more filamentous than are ordinary MLS (32), and it was later found that the envelope had a width of 15 to $25 \mathrm{~nm}$, too large to be a simple unit membrane $(50,51)$. These structures have been found in association with all forms of "green- 
ing" disease that have been described throughout the citrus-growing areas of the world $(5,32$, $50 ; \mathrm{H}$. Su, personal communication). From the nature of their envelope system, it is difficult to consider them, at the present time, as belonging to the Mycoplasmatales, and they might very well represent a new type of phytopathogen. They have not yet been grown in culture.

Structures with apparently a unit membrane envelope were also observed in the phloem elements of citrus seedlings affected with "Stubborn" disease $(28,29,32)$. To ascertain the nature of these mycoplasma-like bodies and to study their role in the etiology of "Stubborn" disease, it was necessary to obtain pure cultures of the agent. At the time, although survival and perhaps even multiplication of plant mycoplasmas in liquid medium had been inferred from indirect evidence $(6,21)$, overt claims for isolation and cultivation of these organisms were not sufficiently convincing or substantiated by published evidence $(9,25,33$, 35 ). Further documentation of these claims, to our knowledge, has not been made. In at least one report (22), there is a suggestion that both fermentative and nonfermentative mycoplasmas are involved.

In attempting to isolate and cultivate the agent associated with citrus "Stubborn" disease, great care was given to the choice of the plant material. It was known that very young citrus leaves, but not mature leaves, from greenhouse-grown, "Stubborn"-affected, sweet orange seedlings were able to transmit the "Stubborn" pathogen with a high frequency of infection (4). Furthermore, the number of MLS in the sieve tubes of such leaves was much higher when the citrus seedlings were grown at high $(32$ C) rather than at low $(24$ C) temperatures (32). The specific effect of high temperatures on symptom expression of "Stubborn" had been noted earlier (40).

Using very young leaves from "Stubborn"affected Madame Vinous sweet orange seedlings grown under phytotron conditions at $32 \mathrm{C}$ in day time $(16 \mathrm{~h})$ and $27 \mathrm{C}$ at night $(8 \mathrm{~h})$, we were able to isolate and grow in pure culture, in liquid broth as well as on solid medium, a mycoplasma-like organism $(49,50)$. That the microorganism cultured was not the result of contamination by an animal mycoplasma was based on the following: (i) the organism was only obtained from "Stubborn"-affected citrus leaves, never from similar healthy control leaves growing next to diseased material; (ii) the organism was isolated and grown consistently in 17 independent experiments with "Stubborn"- affected leaves but never in 11 independent assays with healthy leaf material (50); later, 22 out of 28 experiments gave positive isolations (51); (iii) sterility controls, including uninoculated liquid and solid media, were used in each experiment and never showed any signs of microbial growth.

At the same time, but independently, Calavan and his group in California $(19,20)$ also isolated and grew a mycoplasma-like organism from "Stubborn"-affected young leaves of Madame Vinous sweet orange seedlings which gave the same small, fried-egg type colonies (diameter 0.1 to $0.2 \mathrm{~mm}$ ) as those described by Saglio et al. $(49,50)$. However, cultures obtained in California contained also some spherical cells of undetermined relationship, averaging $0.6 \mu \mathrm{m}$ in diameter and enclosed temporarily in a wall-like coating 55 to $90 \mathrm{~nm}$ thick (19). More recently a pure culture of a mycoplasma-like organism has been obtained by this group (20).

The first mycoplasma-like organisms grown by Saglio et al. (49) were isolated from sweet orange seedlings affected by a California isolate of "Stubborn." Soon after, a mycoplasma-like organism was also isolated from various citrus plants in Morocco $(50,51)$. Our belief that both the California and Morocco isolates are actually mycoplasmas is based upon their colony morphology on agar, the ultrastructure of the organisms in liquid and solid media, their isolation and cultivation in the total absence of any antibiotic, their resistance to penicillin, the absence of reversion to walled forms after 10 passages in penicillin-free medium, and the low guanine plus cytosine content of their deoxyribonucleic acid (DNA) (26 $\pm 1 \mathrm{~mol} \%)$ (51). Additional information on the initial recovery of the two organisms and some preliminary data on their biological and morphological properties were presented elsewhere (J. M. Bové and P. Saglio, Proc. 6th Conf. Int. Org. Citrus Virologists, Swaziland, August 1972, in press; J. M. Bové et al., Conf. N.Y. Acad. Sci., January 1973 , in press).

In this report the serological and biological properties and the taxonomic position of the isolates recovered from "Stubborn" disease of citrus are discussed.

\section{MATERIALS AND METHODS}

Origin of isolates. The California strain $(=\mathrm{C}-189)$ of the "Stubborn" agent was isolated from a Madame Vinous sweet orange seedling graft-infected with "Stubborn" disease. This seedling, together with 23 others, was kindly made available to us by $\mathrm{E}$. C. 
Calavan (Univ. of California, Riverside) and shipped to Versailles (France) in March 1969. The seedling was grown in a Phytotron at Gif-sur-Yvette (France) at 32 $\mathrm{C}$ in daytime $(16 \mathrm{~h}$ supplemented with artificial light) with $80 \%$ relative humidity, and at $27 \mathrm{C}$ at night $(8 \mathrm{~h})$ with $60 \%$ relative humidity.

The seedling was moved to Bordeaux in March 1971 and grown under the conditions described above. For this work, a new isolate of the California strain was prepared from the above seedling in November 1971. This seedling is only one of the plants from which 16 other successful isolations of an MLS had been obtained previously $(49,50)$.

The Morocco strain (R8-A2) of the "Stubborn" agent used in this work was isolated in June 1971. Budwood from a severely "Stubborn"-affected Washington Navel tree was collected in February 1970 in the Tadla area in Morocco and propagated in France on sour orange rootstocks. Several of the budlings showed typical "Stubborn" symptoms. The budling used here is the same as that which had been used in an earlier successful isolation and cultivation experiment (50).

Preparation of inoculum and pure culture of the "Stubborn" agent. Very young leaves (1 to $2 \mathrm{~cm}$ long), showing early leaf symptoms of the disease, were collected from the respective "Stubborn"affected plants, rinsed with water, and ground in a mortar with a small volume of penicillin-free liquid medium (50). The homogenate was passed, under sterile conditions, through a $450-\mathrm{nm}$ membrane filter (Millipore Corp., Bedford, Mass.), and a $0.5-\mathrm{ml}$ portion of the filtrate was added to $3 \mathrm{ml}$ of liquid culture medium containing $20 \mu \mathrm{g}$ of phenol red per $\mathrm{ml}$. The cultures were kept at $32 \mathrm{C}$. After the $\mathrm{pH}$ indicator in the medium had shown a color change from red to yellow, $0.1-\mathrm{ml}$ amounts of the liquid culture were transferred to an agar medium. Fried-egg colonies developing upon the agar medium were transferred back to fresh broth of the same composition as that used initially, and the cultures were incubated at $32 \mathrm{C}$. The organisms were maintained through at least 10 serial passages in broth, with periodic subcultures to agar, before being used in the present work. In addition, prior to detailed characterization studies, the California and Morocco isolates were cloned by selecting single colonies from agar plates seeded with a filtered $(220 \mathrm{~nm})$ broth culture. This procedure was repeated three times.

Culture media. The broth and agar media used to isolate and obtain pure cultures of the two strains reported in this work were described earlier (50). In brief, a conventional mycoplasma medium, containing yeast extract and $20 \%$ ( $\mathrm{vol} / \mathrm{vol}$ ) horse serum, was modified by the addition of sorbitol (7\% wt/vol), tryptone (Difco) $(1 \% \mathrm{wt} / \mathrm{vol})$, sucrose $(1 \% \mathrm{wt} / \mathrm{vol})$, fructose $(0.1 \% \mathrm{wt} / \mathrm{vol})$, and glucose $(0.1 \% \mathrm{wt} / \mathrm{vol})$. This complete sorbitol medium (SMC), without antibiotics, was employed in the initial isolation of the citrus organisms and in studies on the optimal growth temperature, antibiotic sensitivity spectrum, and DNA characteristics of the two strains described above. L-Arginine $\mathrm{HCl}(0.42 \%)$ was also added to this medium for most subsequent investigations on their biochemical properties.
Several other media formulations were also employed for specific biochemical or serological tests, as noted below. These included the usual mycoplasma broth, supplemented with $20 \%$ horse serum, yeast extract, glucose, arginine, and bacterial inhibitors (HSI) (26), and a modification of this medium where the horse serum was replaced with $1 \%$ bovine serum fraction (Difco-0441). The organisms were generally grown in deep broth tubes and under both aerobic and anaerobic $\left(5 \% \mathrm{CO}_{2}\right.$ in nitrogen) conditions on solid media at $32 \mathrm{C}$.

Tests for sterol dependence. The sterol requirement for growth of the California and Morocco strains was determined by both a broth (45) and an agar (16) method. The inoculum for each of these tests was prepared from organisms grown in serum fraction medium (SFM) for 3 days at $32 \mathrm{C}$.

Filtration studies. Actively growing, 48-h-old broth cultures of the two strains in SMC medium were diluted 10 -fold in phosphate-buffered saline (pH 7.4) containing $0.2 \%$ gelatin. Filterability of each diluted suspension was determined with a Swinney hypodermic adaptor and a series of membrane filters with average pore sizes of $100,220,300,450$, and $800 \mathrm{~nm}$. The number of colony-forming units (CFU) per milliliter was determined for each of the original cultures and their respective filtrates by conventional plate count-dilution procedures on HSI agar plates incubated under anaerobic conditions.

Biochemical tests. The procedures used to determine glucose, mannose, and esculin fermentations, arginine and urea hydrolysis, phosphatase production, tetrazolium reduction, serum digestion, and film and spots reaction have been reported elsewhere $(1,56)$. Tests for the presence of pigmented carotenoids were carried out with the technique of Razin and Cleverdon (42). Susceptibility of the plant mycoplasmas to sodium-polyanethol-sulfonate (SPS) was assayed in two separate laboratories by the disk method of Kunze (30). In one laboratory, the test was performed with $5 \%$ SPS ("Grobax" Roche), and organisms were grown on HSI agar plates incubated $(32 \mathrm{C})$ anaerobically for 7 days. The other laboratory employed similar procedures (E. A. Freundt et al., Zentralbl. Bakteriol., in press) but used SMC agar plates. The ability of digitonin to inhibit grow th of the organisms was determined with a tube method slightly modified from that described by Razin and Shafer (44) and with an agar plate method (E. A. Freund et al., in press). In the tube method, various concentrations (7.5 $\mu \mathrm{g}$ to $1000 \mu \mathrm{g} / \mathrm{ml}$ ) of digitonin were added to tubes of SFM broth containing glucose, arginine, and phenol red. The level of digitonin inhibiting growth was obtained by noting those tubes in which a shift in the $\mathrm{pH}$ indicator did not occur. A sample of culture from all tubes was examined by dark-field microscopy to confirm the presence or absence of growth. The plate test was performed essentially as the SPS sensitivity test by using filter paper disks $(6 \mathrm{~mm})$ soaked with $0.02 \mathrm{ml}$ of a $1.5 \%$ (wt/vol) ethanolic solution of digitonin (Merck) and dried overnight at $37 \mathrm{C}$ (E. A. Freund et al., in press).

Action on ery throcytes. Hemoly tic and hemadsorption activity of the isolates for guinea pig erythrocytes 
was determined by procedures previously described (36).

Optimal temperature for growth. A 50-ml amount of antibiotic-free SMC broth medium, containing 100 $\mu \mathrm{Ci}$ of carrier-free $\left({ }^{32} \mathrm{P}\right)$ inorganic phosphate, was inoculated with $0.5 \mathrm{ml}$ of an exponentially growing culture. A series of tubes was filled with $3 \mathrm{ml}$ of the seeded medium and closed tightly. Pairs of tubes were placed at $20,25,29,32,35$, and $37 \mathrm{C}$. Growth was measured in one tube of a pair after $25 \mathrm{~h}$ at the respective temperature and on the second tube after $48 \mathrm{~h}$.

To measure growth in a tube, a $0.3-\mathrm{ml}$ sample was taken from the tube and mixed with $3 \mathrm{ml}$ of $10 \%$ trichloroacetic acid containing $0.1 \mathrm{M} \mathrm{NaH}_{2} \mathrm{PO}_{4}$. The precipitate was filtered on a glass fiber disk and rinsed six times with $5 \mathrm{ml}$ of the trichloroacetic acid solution, once with $1 \mathrm{ml}$ of a mixture of equal volumes of ethanol and ether, and finally twice with 5 $\mathrm{ml}$ of ether. The radioactivity of the acid-insoluble precipitate was counted with a Tracerlab FD 2 gas flow detector. All determinations were done in triplicate. Corrections were made to account for $\left({ }^{32} \mathrm{P}\right)$ decay. Using this technique, the acid-insoluble precipitate from a $0.3-\mathrm{ml}$ sample of an uninoculated liquid medium had a radioactivity averaging 40 counts/min.

Test for serum dependence in SMC. A series of tubes with $2.5 \mathrm{ml}$ of inoculated SMC was prepared in which the serum concentrate decreased by one-half. One tube contained no serum except that present in the inoculum (medium 1, Table 1). All tubes contained $10 \mu \mathrm{Ci}$ of carrier-free ${ }^{32} \mathrm{P}$-labeled inorganic phosphate per $\mathrm{ml}$ and $20 \mu \mathrm{g}$ of phenol red per $\mathrm{ml}$. Growth was measured after $48 \mathrm{~h}$ at $32 \mathrm{C}$ from the incorporation of ${ }^{32} \mathbf{P}$-phosphate in acid-insoluble material as described above.

Antibiotic sensitivity. For each antibiotic examined, a series of tubes with inoculated SMC medium was prepared in which the concentration of the compound (micrograms per milliliter or International Units per milliliter) decreased by one-half. All tubes contained $20 \mu \mathrm{g}$ of phenol red per ml. Growth (at $32 \mathrm{C}$ ) was detected by the color shift of the $\mathrm{pH}$ indicator from red to yellow, and final readings were taken at 72 to 96 h. For most inhibitors studied, the boundary between the tubes where growth occurred and those where growth was inhibited was very sharp.

Amphotericin B (Squibb, France) was treated by the procedure of Rottem (47), and all tubes contained $10 \mu \mathrm{Ci}$ of carrier-free ${ }^{32} \mathrm{P}$-labeled inorganic phosphate per $\mathrm{ml}$ and $20 \mu \mathrm{g}$ of phenol red per ml. Growth was measured after $48 \mathrm{~h}$ at $32 \mathrm{C}$ as described above.

Properties of DNA. DNA was extracted by the method of Marmur (38). The preparations had an optical density ratio of $A_{260} / A_{280}$ between 1.8 and 2.0. Buoyant density $(\rho)$ of DNA in $\mathrm{CsCl}$ was determined by equilibrium density gradient centrifugation at $44,850 \mathrm{rpm}$ for $20 \mathrm{~h}$ at $25 \mathrm{C}$ in the Spinco model $\mathrm{E}$ analytical ultracentrifuge equipped with ultraviolet optics. Initial density of the $\mathrm{CsCl}$ solution was $1.690 \mathrm{~g} / \mathrm{ml}$. The buoyant density of a standard DNA preparation from Escherichia coli was taken to be $1.709 \mathrm{~g} / \mathrm{ml}$. The guanine plus cytosine $(\mathrm{G}+\mathrm{C})$ content was determined from the buoyant density by the following equation (52):

$$
=\frac{0.098(\mathrm{G}+\mathrm{C})}{100}+1.660 \mathrm{~g} / \mathrm{ml}
$$

where $\rho=$ buoyant density in grams per milliliter, and $\mathrm{G}+\mathrm{C}=$ moles percent of guanine plus cytosine. The melting temperature $\left(T_{m}\right)$ was determined in $1 \times \mathrm{SSC}$ buffer by using a Beckman DU spectrophotometer by the method of Marmur and Doty (39). Temperatures in the cuvette were measured with a thermocouple connected to a recorder. The $\mathrm{G}+\mathrm{C}$ content was calculated from the $T_{m}$ by the equation $T_{m}=\mathrm{b}+$ $0.41(\mathrm{G}+\mathrm{C})$, where $T_{m}$ is in degrees $\mathrm{C}$ and $(\mathrm{G}+\mathrm{C})$ refers to the moles percent of guanine plus cytosine (39). Under our conditions, $b$ is found to equal 70.56 when $E$. coli DNA is set to contain $50 \mathrm{~mol} \%$ guanine plus cy tosine.

The genome size was determined from the kinetics of renaturation of single-stranded DNA (54). The DNA was denatured in $0.01 \times$ SSC by heating for 30 $\min$ at $100 \mathrm{C}$ and renatured at a temperature of $T_{m}-25 \mathrm{C}$ in $1 \mathrm{M} \mathrm{Na}^{+}$by the method of Bak et al. (2, $3)$. The decline in absorbancy was measured as a function of time in a Beckman DU spectrophotometer equipped with four thermal spacers and was used to calculate the second-order reaction-rate constant $\left(\mathrm{K}_{2}\right)$ of the renaturation process. The sedimentation coefficient of the heat-denatured DNA $\left(s_{20}\right.$, wen., $\mathrm{pH}^{7}$ ) was determined by boundary sedimentation in $1 \mathrm{M}$ $\mathrm{NaCl}$ with the Spinco model $\mathrm{E}$ analytical ultracentrifuge. Both $\mathrm{K}_{2}$ and $s_{20}$, wen., $\mathrm{pH} 7$ were determined for each preparation of denatured DNA. The genome size (Gs) of the DNA was calculated from the following equation, where $\mathrm{Gs}$ is in daltons and $\mathrm{K}_{2}$ in liter per mole per second:

$$
\mathrm{Gs}=\frac{8.83 \times 10^{8}\left(s_{20, \mathrm{w}}^{\text {den., }}{ }^{7}\right)^{0.911}}{K_{2}}
$$

Polyacrylamide gel electrophoresis. Organisms grown in the SMC broth medium for 4 days at $32 \mathrm{C}$ were sedimented, the cell proteins were solubilized in phenol-acetic acid-water $(2: 1: 0.5, \mathrm{wt} / \mathrm{vol} / \mathrm{vol})$, and the extracts were then examined in polyacrylamide gels containing $5 \mathrm{M}$ urea and $35 \%$ acetic acid (41).

Serological procedures. The growth inhibition (GI) and the metabolic inhibition (MI) tests were carried out essentially as described elsewhere $(7,53)$. The plate immunofluorescence antibody (FA) test was performed both with the direct and indirect techniques $(12,46)$.

\section{RESULTS}

Growth and morphological characteristics. The organisms recovered from the two infected orange seedlings appeared to adapt well to the SMC medium. Broth cultures maintained at 32 $C$ reached maximum turbidity in 2 to 3 days and, by this time, a drop in $\mathrm{pH}$ had occurred $(\mathrm{pH} 7.8$ to 5.0$)$. However, the organisms appeared to survive this environment for several days to a week and were readily subcultured to 
fresh broth. Initial attempts to pass the organisms to conventional mycoplasma broth without sorbitol and fructose were unsuccessful, especially during early ( 21 st to 27 th) serial subcultures. After several additional passages (30th to 40th level) on SMC broth, both the California and Morocco strains were finally adapted to HSI broth and, shortly thereafter, each was successfully transferred and maintained on SFM broth. It was also apparent that glucose and arginine provided some essential growth factors needed to maintain the organisms in both HSI and SFM broths since the strains did not survive in either medium in the absence of these supplements.

Classical fried-egg colonies were observed with both strains when broth cultures were transferred either to SMC or HSI agar plates. The colonies obtained on HSI agar (Fig. 1) were similar in appearance to those previously noted on SMC agar (50). The amount of growth on solid medium always seemed greater when the plates were maintained in an anaerobic environment ( $5 \% \mathrm{CO}_{2}$ in nitrogen). The appearance of bacterial forms was not observed when the strains were grown for over 50 passages in broth or on agar in the absence of penicillin. The two strains did not produce the "film" reaction, although "spots" were apparent on SMC agar plates after 8 days of incubation at $32 \mathrm{C}$. Gram stains of each strain from three different media all showed gram-positive pleomorphic filaments. The organisms possess a helical structure at certain times in their growth cycle, both in situ and in liquid culture, and are infected with a tailed bacteriophage, as is illustrated in another report (8).

Dependence on serum for growth. The growth of the California strain was dependent on the presence of serum in the SMC medium,

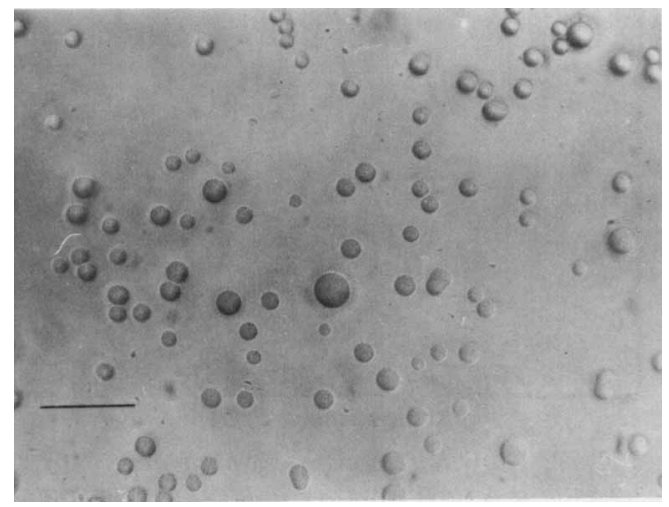

FIG. 1. Colonial morphology of the Morocco strain on horse serum agar (HSI) after 7 days of incubation. Bar, $100 \mu \mathrm{m}$ as illustrated in Table 1. Some growth was obtained with medium 1 to which no serum had been added. This medium was not serumfree since some serum was introduced by the inoculum. The upper limit of serum concentration resulting from the inoculum is $0.4 \%$.

Dependence on sterol for growth. The growth response of the Morocco strain to cholesterol incorporated into a liquid medium is presented in Table 2. The organisms did not grow in a serum-free medium, but a small amount of growth occurred when Tween 80 was added to other supplements in this medium. Cholesterol, in amounts of 5 to 10 $\mu \mathrm{g} / \mathrm{ml}$, provided significant enhancement of growth, although larger amounts $(20 \mu \mathrm{g} / \mathrm{ml})$ appeared inhibitory. An agar plate test for cholesterol requirement showed similar results. Quantities of cholesterol in the range of 1 to $5 \mu \mathrm{g} / \mathrm{ml}$ supported growth on the solid medium, but no growth occurred in the absence of cholesterol. Similar results were obtained in both tests when the California strain was examined.

Temperature for optimal growth. Figure 2 shows that the California strain has a sharp temperature for optimal growth, very close to $32 \mathrm{C}$. At $29 \mathrm{C}$ and $35 \mathrm{C}$ the growth represents only $30 \%$ and $24 \%$, respectively, of that obtained at $32 \mathrm{C}$ during the same period. Practically no growth occurs at $20 \mathrm{C}$ or at $37 \mathrm{C}$. Identical results have also been obtained with the Morocco strain and more recently with a second California isolate (strain 3033). The optimum temperature of $32 \mathrm{C}$ has been observed with strains grown in SMC broth for over 30 passages as well as with those having been tested after only two passages after isolation.

Filterability characteristics. An undiluted broth culture (SMC) of the Morocco strain contained $2 \times 10^{8} \mathrm{CFU} / \mathrm{ml}$, and filtrates yielded $2.0 \times 10^{7}, 1.2 \times 10^{6}, 4.0 \times 10^{5}$, and $3.0 \times 10^{4} \mathrm{CFU} / \mathrm{ml}$ for the $800-, 450-, 300-$, and 220-nm filters, respectively. Since we were unable to pass sufficient amounts of the SMC broth through the $100-n m$ filter with reasonable pressure, counts on this filtrate were not done.

Biochemical characteristics. With the exception noted, identical biochemical reactions were recorded for both organisms examined (Table 3 ). Positive reactions for glucose and mannose fermentation and phosphatase activity were obtained. Negative reactions were observed for esculin fermentation, arginine and urea hydrolysis, and serum digestion. However, the Morocco strain exhibited a positive tetrazolium reduction test whereas the California strain 
TABLE 1. Dependence on serum for growth (California strain)

\begin{tabular}{c|c|c}
\hline $\begin{array}{c}\text { Medium } \\
\text { no. }\end{array}$ & $\begin{array}{c}\text { Horse } \\
\text { serum } \\
\text { concn } \\
(\%)^{a}\end{array}$ & $\begin{array}{c}\text { Incorporation of } \\
\text { 32 P-labeled inorganic } \\
\text { phosphate into acid- } \\
\text { insoluble material } \\
\text { during 69 h (counts/min) }\end{array}$ \\
\hline 1 & & 1,799 \\
2 & 1.25 & 4,316 \\
3 & 2.50 & 9,148 \\
4 & 5.00 & 15,648 \\
5 & 10.00 & 20,915 \\
6 & 20.00 & 23,948 \\
\hline
\end{tabular}

${ }^{a}$ The serum concentrations of the respective media must be corrected for the serum added with the inoculum. The inoculum consisted of $0.5 \mathrm{ml}$ of a culture prepared with SMC medium containing $20 \%$ serum. After having reached the end of the exponential phase of growth, the inoculum was added to 25 $\mathrm{ml}$ of serum-free SMC medium. Samples of $2.0 \mathrm{ml}$ of this inoculated medium were added to a series of tubes containing $0.5 \mathrm{ml}$ of the following solutions, respectively: horse serum $(100 \%$ serum), basal medium $(0 \%$ serum) (basal medium in SMC medium free of serum and yeast extract), basal medium with $50 \%, 25 \%$, $12.5 \%$ or $6.25 \%$ serum. Incorporation of ${ }^{32}$ P-labeled inorganic phosphate from a given medium into lipid-free, acid-insoluble material was determined after $69 \mathrm{~h}$ of growth at $32 \mathrm{C}$.

TABLE 2. Effect of cholesterol on the growth of a citrus organism in a serum-free broth medium

\begin{tabular}{c|c|c}
\hline \multirow{2}{*}{$\begin{array}{c}\text { Cholesterol } \\
\text { in medium } \\
(\mu \mathrm{g} / \mathrm{ml})\end{array}$} & \multicolumn{2}{|c}{$\begin{array}{c}\text { Cell protein }^{a} \\
\text { (Morocco strain) }\end{array}$} \\
\cline { 2 - 3 } & $3 \%$ inoculum & $10 \%$ inoculum \\
\hline $0^{b}$ & 0.04 & 0.03 \\
$0^{c}$ & 0.02 & 0.03 \\
$0^{d}$ & 0.14 & 0.20 \\
1.0 & 0.45 & 0.41 \\
5.0 & 1.75 & 1.57 \\
10.0 & 1.22 & 1.15 \\
20.0 & 0.04 & 0.25 \\
Control $^{e}$ & 1.60 & 1.18 \\
\hline
\end{tabular}

$a$ Expressed in milligrams of protein per $100 \mathrm{ml}$ of medium.

${ }^{b}$ Serum-free medium alone.

${ }^{c}$ Serum-free medium with $0.5 \%$ albumin and $10 \mu \mathrm{g}$ of palmitic acid per $\mathrm{ml}$.

$d$ Serum-free medium with $0.5 \%$ albumin, $10 \mu \mathrm{g}$ of palmitic acid per $\mathrm{ml}$, and $0.01 \%$ Tween 80 .

$e$ Serum fraction broth (1\%).

showed a negative response. Pigmented carotenoids were not produced.

Antibiotic sensitivity. The California and the Morocco strains have the same behavior toward antibiotics and other chemicals (Table 4). In particular, both are resistant to penicillin but highly sensitive to tetracycline. The effect of amphotericin B was examined in more detail (Table 5). Ninety percent or more inhibition was achieved with antibiotic concentrations of $20 \mu \mathrm{g} / \mathrm{ml}$ or higher. The inhibition of both strains by amphotericin B is in agreement with the sterol requirement of the organisms (47).

Action on erythrocytes. The two strains tested produced an alpha-type hemolysis on guinea pig erythrocytes. The California strain hemadsorbed some of the guinea pig cells $(1+)$, whereas the Morocco strain failed to hemabsorb.

Growth inhibition tests with SPS and digitonin. The results of sensitivity tests of the plant organisms to SPS varied between two laboratories. Tests performed on HSI agar indicated that both citrus organisms were sensitive to $5 \%$ SPS since definite zones of growth inhibition ( 4 to $7 \mathrm{~mm}$ ) were observed. In contrast, tests carried out with essentially the same procedure on organisms grown on SMC agar indicated resistance to both $5 \%$ and $20 \%$ concentrations of SPS (E. A. Freundt et al., in press). The results of two different digitonin tests were in general agreement. The tube test on the two strains indicated that growth was inhibited by digitonin concentra-

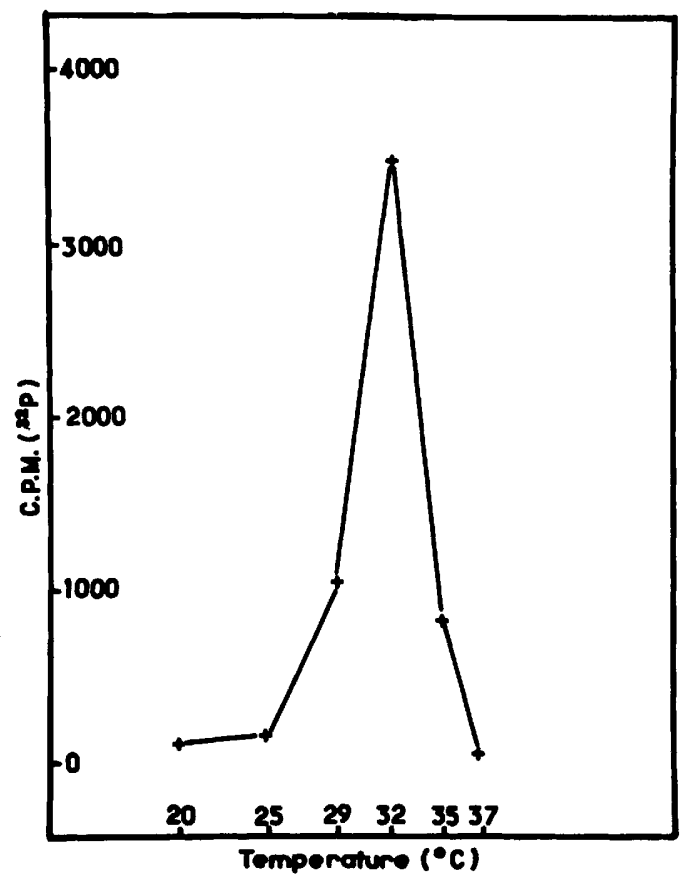

FIG. 2. Growth response of Spiroplasma citri to temperature. Growth was measured by the radioactivity of ${ }^{32}$ P-labeled inorganic phosphate incorporated into acid-insoluble material after $48 \mathrm{~h}$ at the respective temperatures. 
TABLE 3. Properties of Spiroplasma citri

\begin{tabular}{|c|c|c|}
\hline Determination & California strain & Morocco strain \\
\hline Glucose fermentation $\ldots \ldots \ldots \ldots \ldots \ldots$ & + (acid) & $+($ acid $)$ \\
\hline Mannose fermentation $\ldots \ldots \ldots \ldots \ldots \ldots$ & + & + \\
\hline Arginine hydrolysis $\ldots \ldots \ldots \ldots \ldots \ldots$ & - & - \\
\hline Urea hydrolysis $\ldots \ldots \ldots \ldots \ldots \ldots \ldots \ldots$ & - & - \\
\hline Hemolysis (guinea pig red blood cells) $\ldots \ldots \ldots \ldots$ & - & - \\
\hline Hemadsorption (guinea pig red blood cells) . . . . . & + & - \\
\hline Phosphatase activity $\ldots \ldots \ldots \ldots \ldots \ldots$ & + & + \\
\hline Esculin fermentation $\quad \ldots \ldots \ldots \ldots \ldots \ldots$ & - & - \\
\hline Tetrazolium reduction $\ldots \ldots \ldots \ldots \ldots \ldots$ & - & + \\
\hline Serum digestion $\ldots \ldots \ldots \ldots \ldots \ldots \ldots$ & - & - \\
\hline Film and spots $\ldots \ldots \ldots \ldots \ldots \ldots \ldots$ & $-($ spots +$)$ & - \\
\hline Cholesterol requirement $\ldots \ldots \ldots \ldots \ldots \ldots$ & + & + \\
\hline Pigmented carotenoids $\ldots \ldots \ldots \ldots \ldots \ldots$ & - & - \\
\hline Broth cultures $\ldots \ldots \ldots \ldots \ldots \ldots \ldots$ & \multirow{4}{*}{\multicolumn{2}{|c|}{$\begin{array}{l}\text { Produces marked turbidity } \\
\text { Produces classical mycoplasma } \\
\text { colonies, at times with } \\
\text { "fried-egg" appearance } \\
95 \% \text { nitrogen-5\% } \mathrm{CO}_{2} \\
\text { Strains Calif. and Morocco } \\
\text { are identical but distinct } \\
\text { from patterns of other } \\
\text { Mycoplasma and } A \text { choleplasma } \\
\text { species }\end{array}$}} \\
\hline Agar cultures $\ldots \ldots \ldots \ldots \ldots \ldots \ldots \ldots$ & & \\
\hline Preferred atmosphere $\ldots \ldots \ldots \ldots \ldots \ldots \ldots$ & & \\
\hline Cell protein electrophoretic pattern $\ldots \ldots \ldots \ldots$ & & \\
\hline
\end{tabular}

TABLE 4. Sensitivity of Spiroplasma citri to antibiotics and various chemicals

\begin{tabular}{l|c|c}
\hline \multirow{2}{*}{ Antibiotics } & \multicolumn{2}{|c}{$\begin{array}{c}\text { End point concentration range } \\
(\mu \mathrm{g} / \mathrm{ml} \text { or IU/ml) }\end{array}$} \\
\cline { 2 - 3 } & $\begin{array}{c}\text { California } \\
\text { strain }(\mathrm{C}-189)\end{array}$ & $\begin{array}{c}\text { Morocco } \\
\text { strain }(\mathrm{R} 8-\mathrm{A} 2)\end{array}$ \\
\hline Thallium acetate $(\mu \mathrm{g} / \mathrm{ml})$ & $1,280<\mathrm{i}<2,560$ & $2,560<\mathrm{i}$ \\
Erythromycin $(\mu \mathrm{g} / \mathrm{ml})$ & $0.04<\mathrm{i}<0.08$ & $\mathrm{i}<0.02$ \\
Chloramphenicol $(\mu \mathrm{g} / \mathrm{ml})$ & 1.25 \\
Bacitracin $(\mathrm{IU} / \mathrm{ml})$ & $10,240<\mathrm{i}<1.25$ & $80<\mathrm{i} \leqslant 160$ \\
Penicillin "G" $(\mathrm{IU} / \mathrm{ml})$ & $20<\mathrm{i}<40$ & $10,240<\mathrm{i}$ \\
Neomycin $(\mu \mathrm{g} / \mathrm{ml})$ & $0.16<\mathrm{i}<0.32$ & $20<\mathrm{i}<40$ \\
Tetracycline $(\mu \mathrm{g} / \mathrm{ml})$ & $2.5<\mathrm{i}<5$ & $0.16 \leqslant \mathrm{i}<0.32$ \\
Streptomycin $(\mu \mathrm{g} / \mathrm{ml})$ & $1,280<\mathrm{i}$ & $1.25<\mathrm{i} \leqslant 2.5$ \\
Cyclohexymide $(\mu \mathrm{g} / \mathrm{ml})$ & $\mathrm{i}<0.02$ & $1,280<\mathrm{i}$ \\
Actinomycin $\mathrm{D}(\mu \mathrm{g} / \mathrm{ml})$ & $160<\mathrm{i}<320$ & $\mathrm{i}<0.02$ \\
Sulfanilamide $(\mu \mathrm{g} / \mathrm{ml})$ & $20<\mathrm{i}<40$ & $160<\mathrm{i}<320$ \\
Azosulfamide $(\mu \mathrm{g} / \mathrm{ml})$ & $15<\mathrm{i}<25$ & $20<\mathrm{i}<40$ \\
Amphotericin $\mathrm{B}(\mu \mathrm{g} / \mathrm{ml})$ & $15<\mathrm{i}<25$ \\
\hline
\end{tabular}

$a$ Concentrations of inhibitor between which complete growth inhibition (i) occurs (no color shift of phenol red from red to yellow).

tions at or above $30 \mu \mathrm{g} / \mathrm{ml}$ whereas growth occurred in the presence of 7 to $15 \mu \mathrm{g}$ of digitonin per $\mathrm{ml}$. The plate test, using disks saturated with $1.5 \%$ digitonin, showed growth inhibition zones of 9 to $10 \mathrm{~mm}$.

Electrophoretic patterns of cell proteins. The cell protein patterns of the two plant organisms appeared identical to each other (Fig. 3) and were clearly distinct from the patterns of known mycoplasmas $(41,43,48)$.

Serological characteristics. The citrus orga- nisms showed a close serological relatedness according to the results of the GI test (Table 6). Metabolic inhibition of both strains was achieved with the same dilution $(1 / 2560)$ of antiserum to the California strain. In addition, fluorescein-conjugated antiserum to each organism showed reciprocal staining of colonies of both strains when tested in the plate FA test. Extensive serological tests carried out with antisera to over 50 mycoplasmas (Table 7) showed that all failed either to inhibit the 
TABLE 5. Inhibition by amphotericin B

\begin{tabular}{|c|c|c|c|c|}
\hline \multirow{3}{*}{$\begin{array}{l}\text { Amphotericin B } \\
\qquad(\mu \mathrm{g} / \mathrm{ml})\end{array}$} & \multicolumn{4}{|c|}{$\begin{array}{c}\text { Incorporation of }{ }^{32} \text { P-labeled inorganic phosphate } \\
\text { into acid-insoluble material }\end{array}$} \\
\hline & \multicolumn{2}{|c|}{ California strain } & \multicolumn{2}{|c|}{ Morocco strain } \\
\hline & Counts/min & $\%$ inhibition & Counts/min & $\%$ inhibition \\
\hline 0 & 12,847 & 0 & 14,066 & 0 \\
\hline 2.5 & 12,001 & 7 & 12,402 & 12 \\
\hline 5.0 & 10,147 & 21 & 7,877 & 44 \\
\hline 10.0 & 7,036 & 46 & 6,866 & 51 \\
\hline 15.0 & 4,910 & 62 & 2,168 & 85 \\
\hline 20.0 & 1,169 & 91 & 456 & 97 \\
\hline 30.0 & 640 & 95 & 53 & 99 \\
\hline 40.0 & 94 & 99 & 0 & 100 \\
\hline 80.0 & 220 & 98 & 72 & 99 \\
\hline
\end{tabular}

growth or to stain colonies of the two citrus agents.

Properties of DNA. The $\mathrm{G}+\mathrm{C}$ content of the DNA from the California strain was found to be $26.35( \pm 1.45) \mathrm{mol} \%$ as determined from the buoyant density (Table 8 ). In several experiments, DNA preparations from the California and Morocco strains, respectively, were banded together in $\mathrm{CsCl}$. Only one band was obtained, the buoyant density of which was identical to that of the DNA from the California strain alone. Under the same conditions, $A$. laidlawii DNA had a $\mathrm{G}+\mathrm{C}$ content of $32.6 \mathrm{~mol} \%$, and that of calf thymus averaged around $39.4 \%$.

The $\mathrm{G}+\mathrm{C}$ content was also determined from the melting temperature taken as the temperature corresponding to $50 \%$ of the total increase in optical density (Fig. 4). A value close to 25 mol \% has been found in the case of the California strain (Table 9).

In agreement with its low $\mathrm{G}+\mathrm{C}$ content, the DNA of the citrus organism, studied by X-ray diffraction, occurs only in the B lattice configuration whatever the relative humidity ( $R$. W. Horn, personal communication).

The genome size of the California and Morocco strains was determined from renaturation kinetics (54) in comparison with that of Acholeplasma axanthum (Bovine $\mathrm{K}$, strain B 107 PA) and Acholeplasma laidlawii A. Figure 5 illustrates the kinetics of the second-order renaturation reaction. Table 10 shows that both strains have a genome size of the order of $10^{9}$ daltons, similar to that of strains of Acholeplasma species even though the citrus organisms appear to require sterol for growth.

\section{DISCUSSION}

The data presented here indicate that the microorganisms obtained from "Stubborn"- affected plant material are not the result of contamination by human or animal mycoplasmas. The similarity in morphology of both the cultured organism and the organism observed in the sieve tubes of affected citrus plants (8) provides additional evidence that the organism grown was of plant origin. It is also apparent that the organism has unique characteristics not shown by organisms of the order Mycoplasmatales.

The overall pattern, described here and in a second paper (8), of the properties of the two organisms recovered from citrus plants with the same disease is not unequivocal from a taxonomic viewpoint and hence raises some rather intriguing problems with respect to their classification.

The colonial and cellular morphology, the ultrastructure (including the apparent lack of a cell wall), filterability, absolute resistance to penicillin, inhibition of growth by antibody, lack of bacterial reversion, DNA characteristics (low $\mathrm{G}+\mathrm{C}$ ratio, small genome size), and the cultural properties of the organism all seem to allow its classification within the class Mollicutes, order Mycoplasmatales (14, 17, 18). However, many of these same characteristics are also shared by bacterial L-phase organisms and possibly other microorganisms. In addition, the citrus organism possesses other attributes, some of which indicate that it might represent a new mycoplasma, and others which indicate that it is not a mycoplasma at all. Helical shape and motility need not rule out inclusion in the order Mycoplasmatales. The shape might be considered a new characteristic which would require a change in the description of the higher taxa in which this organism is placed. However, motility and the presence of surface material much like that on the outer layer of the "Stubborn" agent has been observed in some 
mycoplasmas, as is noted in ultrastructural studies on the citrus organism (8).

The nature of this outer layer is of importance in several respects other than bearing a possible relationship to shape and motility. For example, does it play a role in the gram-positive staining of the "Stubborn" agent? This finding complicates the problem of classification, inas-

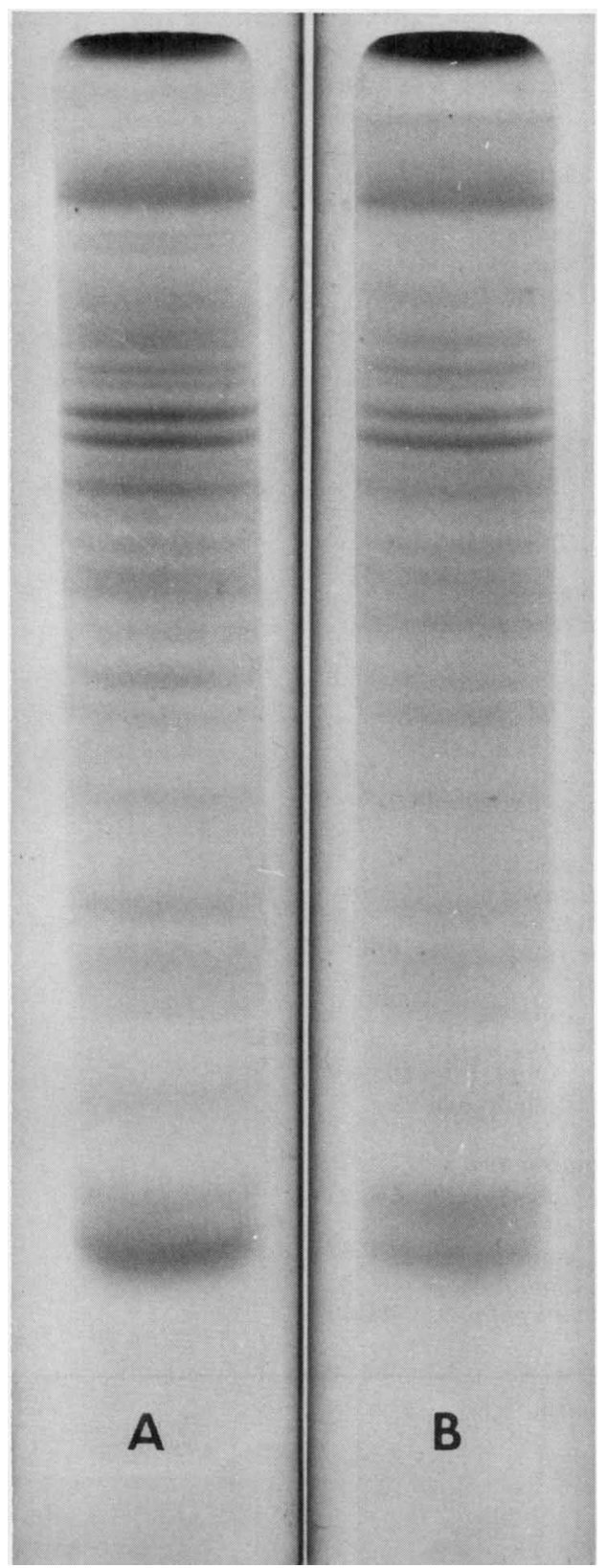

FIG. 3. Electrophoretic patterns of the cell proteins of Spiroplasma citri. A, California strain; B, Morocio strain.
TABLE 6. Growth inhibition tests with citrus isolates

\begin{tabular}{l|c|c}
\hline \multirow{2}{*}{\multicolumn{1}{c|}{ Antigens $^{a}$}} & $\begin{array}{c}\text { Zones of growth } \\
\text { inhibition (mm) } \\
\text { with rabbit anti- } \\
\text { sera to strains }\end{array}$ \\
\cline { 2 - 3 } & California & Morocco \\
\hline $\begin{array}{l}\text { California strain } \\
\text { Undiluted broth culture } \\
\text { 1:50 dilution }\end{array}$ & $3-4$ & $4-6$ \\
\multirow{2}{*}{$\begin{array}{l}\text { Morocco strain } \\
\text { Undiluted broth culture } \\
\text { 1:50 dilution }\end{array}$} & $6-8$ & $7-9$ \\
\hline
\end{tabular}

a Antigens prepared from $48 \mathrm{~h}$ HSI broth cultures plated to HSI agar medium. Incubated $32 \mathrm{C}$ in $5 \%$ $\mathrm{CO}_{2}$ in nitrogen.

much as all known members of the order Mycoplasmatales and even L-phase organisms are gram negative, a situation thought to be compatible with current beliefs that retention of the gram stain complex depends upon the presence of a cell wall of special structure. It is pertinent to point out here that definitions of the order Mycoplasmatales state that organisms in this order not only should be devoid of cell wall but also must lack the ability to synthesize mucopeptide and its precursors (i.e., muramic or diaminopimelic acids) $(15,17,18)$. This requirement was added to the definition to exclude the L-phase of bacteria. At present, the chemical nature of the outer layer of the "Stubborn" agent is unknown, but it may function in some manner analogous to bacterial cell walls, namely, as a site for bacteriophage receptors. The finding ( 8 ) of a bacteriophage of classic type B morphology in and on this microorganism further complicates the taxonomic problem because of the traditional concept that such tailed bacteriophages do not attack wall-less microorganisms.

Obviously, the shape and motility of the "Stubborn" agent invites comparison with members of the order Spirochaetales. All of the latter, however, possess axial filaments or other flagella-like appendages as well as a well-defined outer layer or periplast of triple-layered and sometimes periodic construction (23). The latter may be the site of the muramic acid isolated from spirochetes $(23,57)$ and may therefore represent a modified cell wall (34). Whether or not the outer layer of the "Stubborn" agent is similar to that of the Spirochaetales must await further ultrastructural and biochemical studies, including a search for cell-wall precursors. These results will influence 
TABLE 7. Antisera prepared against the mycoplasmas and acholeplasmas listed were used in immunofluorescence and growth inhibition tests against the two agents recovered from "Stubborn" affected citrus

\begin{tabular}{|c|c|}
\hline Species and strain & Species and strain \\
\hline 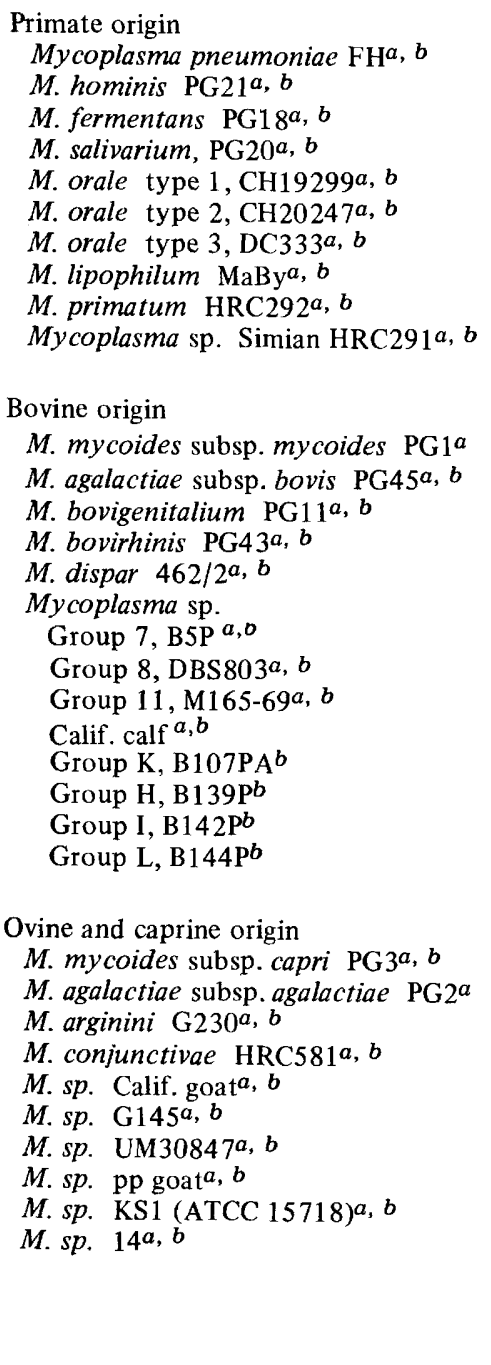 & 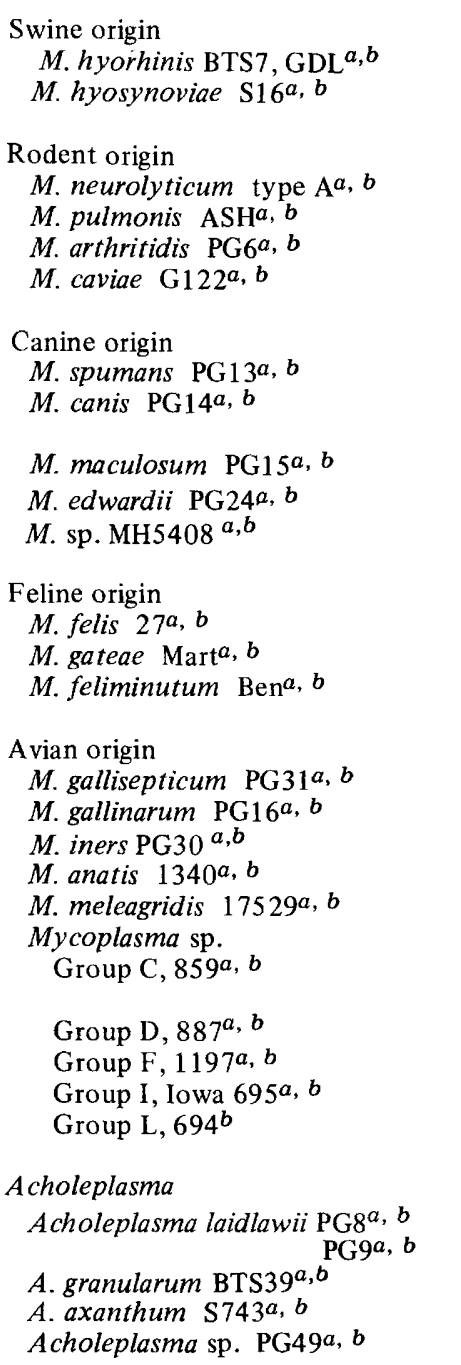 \\
\hline
\end{tabular}

\footnotetext{
${ }^{a}$ Antisera tested by plate immunofluorescence to plant isolates.

$b$ Antisera tested by growth inhibition to plant isolates.
} 
TABLE 8. Buoyant density and $G+C$ content of DNA from Spiroplasma citri (California strain)

\begin{tabular}{|c|c|c|}
\hline $\begin{array}{c}\text { Source of } \\
\text { DNA }\end{array}$ & $\begin{array}{c}\text { Buoyant density } \\
\text { of DNA }(\mathrm{g} / \mathrm{ml})\end{array}$ & $\begin{array}{c}G+C \text { content } \\
(\mathrm{mol} \%)\end{array}$ \\
\hline $\begin{array}{l}\text { S. citri (California) } \\
\text { Range (11 tests) } \\
\text { Mean }\end{array}$ & $\begin{array}{c}1.6844-1.6873 \\
1.6861\end{array}$ & $\begin{array}{c}24.9-27.8 \\
26.35\end{array}$ \\
\hline $\begin{array}{l}\text { Calf thymus (control) } \\
\text { Range (3 tests) } \\
\text { Mean }\end{array}$ & $\begin{array}{c}1.6983-1.6991 \\
1.6986\end{array}$ & $\begin{array}{c}39.1-39.9 \\
39.4\end{array}$ \\
\hline Acholeplasma laidlawii (control) & 1.6919 & 32.6 \\
\hline
\end{tabular}

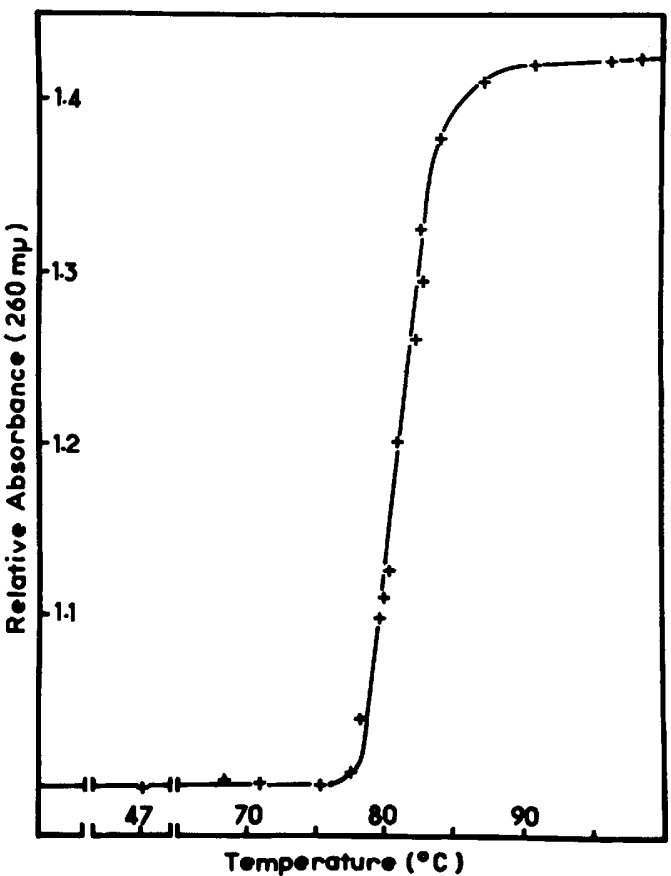

FIG 4. Thermal denaturation curve of Spiroplasma citri DNA (California strain) dissolved in $0.15 \mathrm{M} \mathrm{NaCl}$ plus $0.015 \mathrm{M}$ sodium citrate. the decision on the assignment of this microorganism to either the class Mollicutes or the class Schizomycetes. However, information presented elsewhere (J. M. Bové et al., Ann. N.Y. Acad. Sci., in press) seems to indicate that the plant agent is not serologically related to the several spirochetes tested.

Even though the classification of the "Stubborn" agent as to class, order, and family is dubious at present, we feel that it is sufficiently distinct from other microorganisms to warrant its assignment at least to a new genus and species. More particularly, the studies reported here show that the two serologically identical organisms recovered from "Stubborn"-affected citrus plants are serologically distinct from recognized Mycoplasma and Acholeplasma species. A comparison of the cultural, biochemical, and biophysical properties of the organisms, presented here and in another publication (8), supports the serological results and confirms their unique nature. We therefore regard these organisms as belonging to a new genus, for which we propose the name Spiroplasma (Gr. n. spira a coil, spiral; Gr. neut. n. plasma something formed or molded, a form; M.L. neut. n. Spiroplasma spiral form). The term "Spiroplasma" was suggested earlier (11) for

TABLE 9. Melting temperature and $G+C$ content of DNA from Spiroplasma citri (California strain)

\begin{tabular}{l|c|c}
\hline \multicolumn{1}{c|}{$\begin{array}{c}\text { Source of } \\
\text { DNA }\end{array}$} & $T_{m}(\mathrm{C})$ & $\begin{array}{c}\mathrm{G}+\mathrm{C} \text { content } \\
\text { (mol \%) }\end{array}$ \\
\hline $\begin{array}{l}\text { S. citri (California) } \\
\text { Range (4 tests) } \\
\text { Mean }\end{array}$ & $\begin{array}{c}80.5-81.0 \\
\text { 80.75 }\end{array}$ & $24.3-25.5$ \\
$\begin{array}{l}\text { Calf thymus (control) } \\
\text { Range (5 tests) } \\
\text { Mean }\end{array}$ & $86.25-88.25$ & 24.9 \\
$\begin{array}{l}\text { E. coli (control) } \\
\text { Mean (5 tests) }\end{array}$ & 86.96 & $38.5-43.0$ \\
& & 40.1 \\
\hline
\end{tabular}




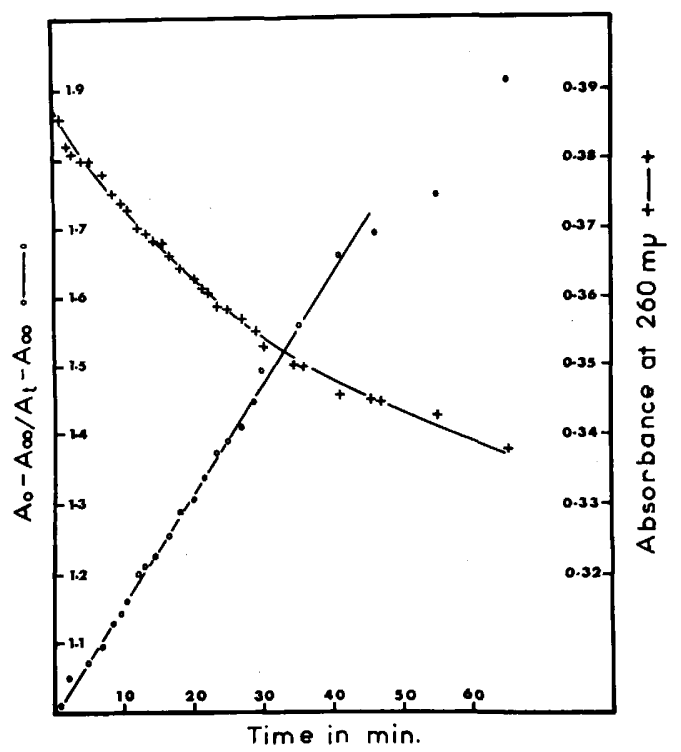

FIG. 5. Kinetics of renaturation with Spiroplasma citri DNA (Morocco strain). A, +, Renaturation curve in $1 \mathrm{M} \mathrm{Na}^{+} ; \mathrm{B}$, O, second-order rate plot for the renaturation curve. another helical, mycoplasma-like, plant-derived organism observed, but not recovered in culture, in corn stunt disease. The two isolates of the "Stubborn" agent (namely, the Morocco and the California strains) are placed in a single species, $S$. citri sp. n. (L. mas. n. citrus the citrus; M. L. mas. n. Citrus generic name; M. L. gen. n. citri of Citrus), the type species of the genus Spiroplasma. The Morocco strain (=R8A2) is designated as the type strain of $S$. citri. It has been deposited in the American Type Culture Collection, Rockville, Maryland, as ATCC 27556, and the California strain (=C-189) has been deposited as ATCC 27665.

\section{ACKNOWLEDGMENTS}

We wish to thank D. Taylor-Robinson for performing metabolic-inhibition and growth-inhibition tests with the two organisms described here on 17 antisera prepared in his laboratory to various acid-producing mycoplasmas and J. Lund for performing immunofluorescence tests with the indirect method. We also gratefully acknowledge the excellent technical assistance of C. W. Renshawe, N. G. Ramsburg, C. M.

TABLE 10. Genome size of Spiroplasma citri

\begin{tabular}{|c|c|c|c|}
\hline $\begin{array}{l}\text { Source of } \\
\text { DNA }\end{array}$ & $\begin{array}{l}\text { Sedimentation } \\
\text { coefficient } \\
\text { (density, } \mathrm{pH} 7 \text { ) }\end{array}$ & $\begin{array}{l}\text { Rate constant } \\
\text { (liter } / \mathrm{mol} / \mathrm{s})\end{array}$ & $\begin{array}{c}\text { Genome size }\left(\times 10^{-8}\right. \\
\text { daltons })\end{array}$ \\
\hline \multicolumn{4}{|l|}{$\begin{array}{l}\text { S. citri (California) } \\
\text { DNA prepn } 1\end{array}$} \\
\hline Range (5 tests) & $13.0-31.8$ & $8.55-17.7$ & $9.0-11.6$ \\
\hline Mean & 20.4 & 12.6 & 10.7 \\
\hline DNA prepn 2 & & & \\
\hline Range (3 tests) & $13.2-15.3$ & $9.5-11.5$ & $8.0-10.8$ \\
\hline Mean & 14.4 & 10.6 & 9.6 \\
\hline \multicolumn{4}{|l|}{ S. citri (Morocco) } \\
\hline \multicolumn{4}{|l|}{ DNA prepn 1} \\
\hline Range (2 tests) & $15.4-16.9$ & $11.0-13.5$ & $8.5-9.7$ \\
\hline Mean & 16.1 & 12.2 & 9.1 \\
\hline \multicolumn{4}{|l|}{ DNA prepn 2} \\
\hline Range (4 tests) & $23.5-33.3$ & $12.8-16.3$ & $11.2-13.2$ \\
\hline Mean & 28.2 & 15.1 & 12.1 \\
\hline \multicolumn{4}{|l|}{ DNA prepn 3} \\
\hline Range (4 tests) & $14.5-18.2$ & $11.5-14.4$ & $8.7-9.6$ \\
\hline Mean & 16.3 & 10.4 & 9.0 \\
\hline \multicolumn{4}{|l|}{ Acholeplasma laidlawii A } \\
\hline Range (5 tests) & $11.3-21.5$ & $7.0-14.9$ & $9.7-12.4$ \\
\hline Mean & 17.4 & 10.8 & 11.1 \\
\hline \multicolumn{4}{|l|}{ Acholeplasma axanthum } \\
\hline Range (5 tests) & $13.3-21.0$ & $8.5-14.6$ & $8.5-12.7$ \\
\hline Mean & 16.7 & 10.9 & 10.7 \\
\hline
\end{tabular}


Blood, J. C. Vignault, and M. W. Tully. Part of this work was supported by a grant from Institut Français de Recherches Fruitières Outre Mer (IFAC).

\section{REPRINT REQUESTS}

Address requests for reprints to: Dr. J. M. Bové Station de Physiologie et de Biochimie Vegetales, Centre de Recherches de Bordeaux, 33 Pont-de-laMaye, France.

\section{LITERATURE CITED}

1. Aluotto, B. B., R. G. Wittler, C. O. Williams, and J. E. Faber. 1970. Standardized bacteriologic techniques for the characterization of $\mathrm{Myco}$ plasma species. Int. J. Syst. Bacteriol. 20:35-58.

2. Bak, A. L., F. T. Black, C. Christiansen, and E. A. Freundt. 1969. Genome size of Mycoplasma DNA. Nature (London) 224:1 209-12 10.

3. Bak, A. L., C. Christiansen, and A. Stenderup. 1970. Bacterial genome sizes determined by DNA renaturation studies. J. Gen. Microbiol. 64:377-380.

4. Calavan, E. C., E. O. Olson, and D. W. Christiansen. 1972. Transmission of the stubborn pathogen in citrus by leaf-piece grafts, p. 11-14. In W. C. Price (ed.), Proc. 5th Conf. Int. Org. Citrus Virol., Univ. of Florida Press, Gainesville, Fla.

5. Chen, M., T. Miyakawa, and C. Matsui. 1971. Mycoplasma-like bodies associated with Likubindiseased Ponkan citrus. Phytopathology 61:598.

6. Chen, T. A., and R. R. Granados. 1970. Plant pathogenic mycoplasma-like organisms: maintenance in vitro and transmission to Zea mays $\mathrm{L}$. Science 167:1633-1636.

7. Clyde, W. A. Jr. 1964. Mycoplasma species identification based upon growth inhibition by specific antisera. J. Immunol. 92:958-965.

8. Cole, R. M., J. G. Tully, T. J. Popkin, and J. M. Bove. 1973. Morphology, ultrastructure, and bacteriophage infection of the helical mycoplasma-like organism (Spiroplasma citri gen. n., sp. n.) cultured from "stubborn" disease of citrus. J. Bacteriol. 115:000-000.

9. Cousin, M. T., T. Staron, A. Faivre-Amiot, and J. P. Moreau. 1970. Etude ultrastructurale de cultures sur milieux semi-synthetiques de microorganismes obtenus a partir de plantes atteintes de Stolbur et de Phyllodie. Annu. Rev. Phytopathol. 2:245-252.

10. Davis, R. E., and R. F. Whitcomb. 1971. Mycoplasmas, rickettsiae, and chlamydiae: possible relation to yellows diseases and other disorders of plants and insects. Annu. Rev. Phytopathol. 9:119-154.

11. Davis, R. E., and J. F. Worley. 1973. Spiroplasma: motile, helical microorganism associated with corn stunt disease. Phytopathology 63:403-408

12. Del Giudice, R. A., N. F. Robillard, and T. R. Carski. 1967. Immunofluorescence identification of Mycoplasma on agar by use of incident illumination. J. Bacteriol. 93: 1205-1209.
13. Doi, U., M. Teranaka, K. Yora, and H. Asuyama. 1967. Mycoplasma or PLT group-like microorganisms found in the phloem elements of plants infected with mulberry dwarf, potato witches' broom, aster yellows, or paulownia witches' broom. Ann. Phytopathol. Soc. Japan. 33:259266.

14. Edward, D. G. ff. 1953. A difference in growth requirements between bacteria in the L-phase and organisms of the pleuropneumonia group. J. Gen. Microbiol. 8:256-262.

15. Edward, D. G. ff. 1967. Problems of classification. An introduction. Ann. N.Y. Acad. Sci. 143:7-8.

16. Edward. D. G. ff. 1971. Determination of sterol requirement for Mycoplasmatales. J. Gen. Microbiol. 69:205-210.

17. Edward, D. G. ff, and E. A. Freundt. 1967. Classification of the Mycoplasmatales, p. 147-200. In L. Hay flick (ed.), The Mycoplasmatales and the L-phase of bacteria. Appleton-Century-Crofts, New York.

18. Edward, D. G. ff, E. A. Freundt, R. M. Chanock, J. Fabricant, L. Hayflick, R. M. Lemcke, S. Razin, N. L. Somerson, J. G. Tully, and R. G. Wittler. 1972. Proposal for minimal standards for descriptions of new species of the order Mycoplasmatales. Int. J. Syst. Bacteriol. 22:184-188.

19. Fudl-Allah, A., E. C. Calavan, and E. C. K. Igwegbe. 1971. Culture of a mycoplasma-like organism associated with stubborn disease of citrus. Phy topathology 61:1321.

20. Fudl-Allah, A., E. C. Calavan, and E. C. K. Igwegbe. 1972. Culture of a mycoplasma-like organism associated with stubborn disease of citrus. Phy topathology 62:729-731.

21. Giannotti, J., C. Vago, D. Czarnecki, and G. Kuhl. 1969. Developpement en milieu liquide de Mycoplasmes de végétaux. C. R. Acad. Agric. 10:1044-1052.

22. Giannotti, J., C. Vago, G. Marchoux, G. Devauchelle, and D. Czarnecki. 1972. Caractérisation par la culture in vivo de souches de mycoplasmes correspondant à huit maladies différentes de plantes. C. R. Acad. Sci. 274:330-333.

23. Glauert, A. M., and M. J. Thornley. 1969. The topography of the bacterial cell wall. Annu. Rev. Microbiol. 23: 159-198.

24. Hampton, R. O. 1972. Mycoplasmas as plant pathogens: perspectives and principles. Annu. Rev. Plant Physiol. 23: 389418.

25. Hampton, R. O., J. O. Stevens, and T. C. Allen. 1969. Mechanically transmissible Mycoplasma from naturally infected peas. Plant Dis. Reporter 53:499-503.

26. Hayflick, L. 1965. Tissue cultures and mycoplasmas. Tex. Rep. Biol. Med. 23:285-303.

27. Hull, R. 1971. Mycoplasma-like organisms in plants. Rev. Plant Pathol. 50:121-130.

28. Igwegbe, E. C. K., and E. C. Calavan. 1970. Occurrence of mycoplasma-like bodies in phloem of stubborn-infected citrus seedlings. Phytopathology 60:1525-1526.

29. Igwegbe, E. C. K., E. C. Calavan, and A. 
Fudl-Allah. 1971. Inclusion in a mycoplasma-like organism associated with stubborn disease of citrus. Phy topathology 61:1321-1322.

30. Kunze, M. 1971. Natrium-polyanethol-sulfonat als diagnostisches Hilfsmittel bei der Differenzierung von Mykoplasmen. Zentralbl. Bakteriol. Abt. 1 Orig. 216:501-505.

31. Lafléche, D., and J. M. Bové. 1970. Structures de type mycoplasme dans les feuilles d'orangers atteints de la maladie du "Greening." C. R. Acad. Sci. 270:1915-1917.

32. Lafléche, D., and J. M. Bové. 1970. Mycoplasmes dans les agrumes atteints de "greening", de "Stubborn" ou de maladies similaires. Fruits 25:455-465.

33. Lin, S. C., C. S. Lee, and R. J. Chiu. 1970. Isolation and cultivation of, and inoculation with, a Mycoplasma causing white leaf disease of sugarcane. Phy topathology 60:795-797.

34. Listgarten, M. A., and S. S. Socransky. 1964. Electron microscopy of axial fibrils, outer envelope, and cell division of certain oral spirochetes. J. Bacteriol. 88:1087-1103.

35. Lombardo, G., and P. Pignattelli. 1970. Cultivation in a cell-free medium of a mycoplasma-like organism from Vinca rosea with phyllody symptoms of the flowers. Ann. Microbiol. 20:84-89.

36. Manchee, R. J., and D. Taylor-Robinson. 1968. Hemadsorption and hemagglutination by mycoplasmas. J. Gen. Microbiol. 50:465478.

37. Maramorosch, K., R. R. Granados, and H. Hirumi. 1970. Mycoplasma diseases of plants and insects. Advan. Virus Res. 16:135-193.

38. Marmur, J. 1961. A procedure for the isolation of deoxyribonucleic acid from microorganisms. J. Mol. Biol. 3:208-218.

39. Marmur, J., and P. Doty. 1962. Determination of the base composition of deoxyribonucleic acid from its thermal denaturation temperature. J. Mol. Biol. 5: 109-118.

40. Olson, E. O., and B. Rogers. 1969. Effect of temperature on expression and transmission of stubborn disease of citrus. Plant Dis. Reporter 53:45-49.

41. Razin, S. 1968. Mycoplasma taxonomy studied by electrophoresis of cell proteins. J. Bacteriol. 96:687-694.

42. Razin, S., and R. C. Cleverdon. 1965. Carotenoids and cholesterol in membranes of Mycoplasma laidlawii. J. Gen. Microbiol. 41:409-415.

43. Razin S., and S. Rottem. 1967. Identification of Mycoplasma and other microorganisms by polyacrylamide gel electrophoresis of cell proteins. J. Bacteriol. 94:1807-1810.

44. Razin, S., and Z. Shafer. 1969. Incorporation of cholesterol by membranes of bacterial L-phase variants. J. Gen. Microbiol. 58:327-339.

45. Razin, S., and J. G. Tully. 1970. Cholesterol requirement of mycoplasmas. J. Bacteriol. 102:306-310.

46. Rosendal, S., and F. T. Black. 1972. Direct and indirect immunofluorescence of unfixed and fixed Mycoplasma colonies. Acta Pathol. Microbiol. Scand. 80:615-622.

47. Rottem, S. 1972. Differentiation of sterolrequiring from sterol-nonrequiring mycoplasmas by amphotericin B. Appl. Microbiol. 23:659-660.

48. Rottem, S., and S. Razin. 1967. Electrophoretic patterns of membrane proteins of Mycoplasma. J. Bacteriol. 94:359-364.

49. Saglio, P., D. Laflèche, C. Bonissol, and J. M. Bové 1971. Culture in vitro des mycoplasmes associés au "Stubborn" des agrumes et leur observation au microscope électronique. C. R. Acad. Sci. 272:1387-1390.

50. Saglio, P., D. Laflèche, C. Bonissol, and J. M. Bové. 1971. Isolement, culture et observation au microscope électronique des structures de type mycoplasme associées a la maladie du Stubborn des agrumes et leur comparaison avec les structures observées dans le cas de la maladie du Greening des agrumes. Physiol. Veg. 9:569-582.

51. Saglio, P., D. Laflèche, M. Lhospital, G. Dupont, and J. M. Bové. 1972. Isolation and growth of citrus mycoplasmas, p. 187-203. In K. Elliott and J. Birth (ed.), Pathogenic mycoplasmas, CIBA Foundation Symposium (25-27 January 1972). ASP (Elsevier Excerpta Medica, North Holland), Amsterdam.

52. Schildkraut, C. L., J. Marmur, and P. Doty. 1962. Determination of the base composition of deoxyribonucleic acid from its buoyant density in $\mathrm{CsCl}$. J. Mol. Biol. 4:430-443.

53. Taylor-Robinson, D., R. H. Purcell, D. C. Wong, and R. M. Chanock. 1966. Colour test for the measurement of antibody to certain Mycoplasma species based upon the inhibition of acid production. J. Hyg. 64:91-104.

54. Wetmur, J. G., and N. Davidson. 1968. Kinetics of renaturation of DNA. J. Mol. Biol. 31:349-370.

55. Whitcomb, R. F., and R. E. Davis. 1970. Mycoplasma and phytoarboviruses as plant pathogens persistently transmitted by insects. Annu. Rev. Entomol. 15:405-464.

56. Williams, C. O., and R. G. Wittler. 1971. Hydrolysis of aesculin and phosphatase production by members of the order Mycoplasmatales which do not require sterol. Int. J. Syst. Bacteriol. 21:73-77.

57. Yanagawa, R., and S. Faine. 1966. Morphological and serological analysis of leptospiral structure. Nature (London) 211:823-826.

58. Zelcer, A., M. Bar-Joseph, and G. Loebenstein. 1971. Mycoplasma-like bodies associated with little-leaf disease of citrus. Israel J. Agric. Res. 21:137-142. 